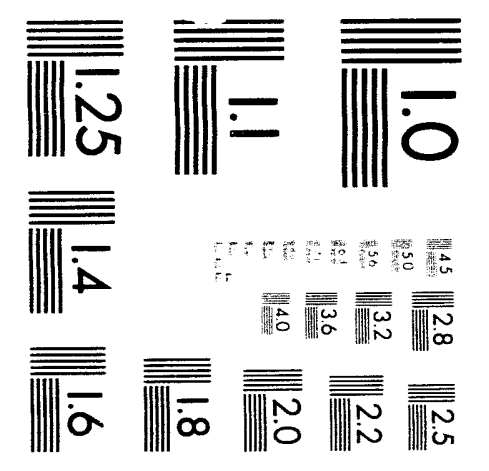



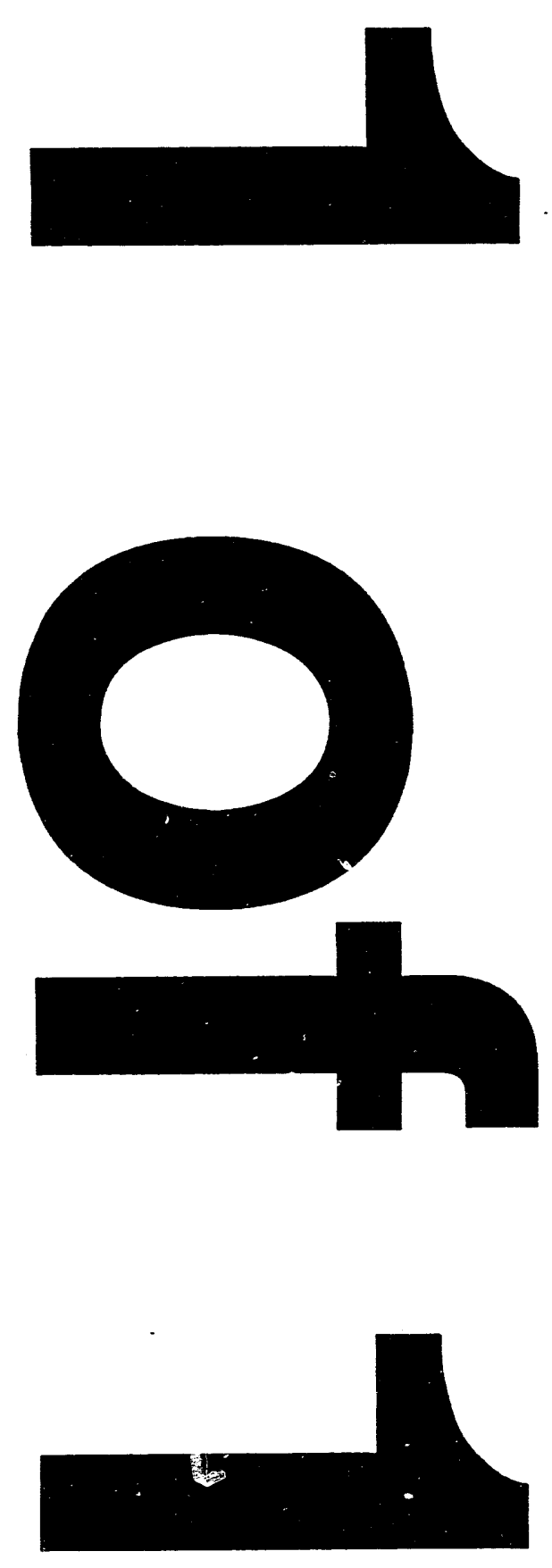


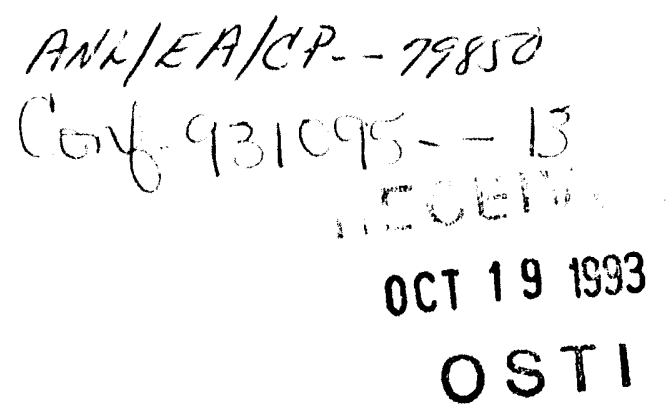

\title{
AQUIFER CHARACTERIZATION AND GROUNDWATER MODELING IN SUPPORT OF REMEDIAL ACTIONS AT THE WELDON SPRING SITE
}

\author{
by
}

\section{Lisa A. Durham}

Argonne National Laboratory, Argonne, IL

and

Jeffrey D. Carman

Jacobs Engineering Group, St. Charles, MO

\section{DISCLAIMER}

This report was prepared as an accnunt of work sponsored by an agency of the United States Government. Neither the United States Gnvernment nor any agency thereof, nor any of their

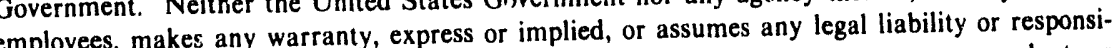
bility for the accuracy, completeness, or usefulness of any information, apparatus, product, or process disclosed, or represents that its use would not infringe privately owned rights. Referprocess disclosed, or repric commercial product, process, or service by trade name, trademark,

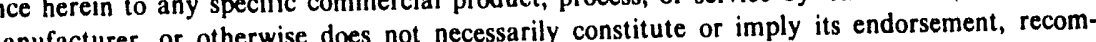
manufacturer, or otherwise the United States Government or any agency thereof. The views mendation, or favoring by the United States Governest and opinions of authors expressed herein do not

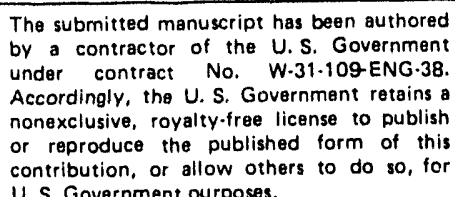


AQUIFER CHARACTERIZATION AND GROUNDWATER MODELING IN SUPPORT

OF REMEDIAL ACTIONS AT THE WELDON SPRING SITE

Lisa A. Durham

Argonne National Laboratory, Argonne, Ill.

Jeffrey D. Carman

Jacobs Engineering Group, St. Charles, Mo.

\begin{abstract}
Aquifer characterization studies were performed to develop a hydrogeologic understanding of an unconfined shallow aquifer at the Weldon Spring site west of St. Louis, Missouri. The 88-ha site became contaminated because of uianium and thorium processing and disposal activities that took place from the 1940s through the 1960s. Slug and pumping tests provided valuable information on the lateral distribution of hydraulic conductivities, and packer tests and lithologic information were used to determine zones of contrasting hydrologic properties within the aquifer. A three-dimensional, finite-clement groundwater flow model was developed and used to simulate the shallow groundwater flow system at the site. The results of this study show that groundwater flow through the system is predominantly controlled by a zone of fracturing and weathering in the upper portion of the limestone aquifer. The groundwater flow model, developed and calibrated from field investigations, improved the understanding of the hydrogeology and supported decisions regarding remedial actions at the site. The results of this study illustrate the value, in support of remedial actions, of combining field investigations with numerical modeling to develop an improved understanding of the hydrogeology at the site.
\end{abstract}

\title{
INTRODUCTION
}

The Weldon Spring site is located in St. Charles County, Missouri, about $48 \mathrm{~km}$ west of St. Louis (Figure 1). The site is listed on the National Priorities List, and cleanup activities are currently being conducted by the U.S. Department of Energy (DOE). The chemical plant area of the Weldon Spring site became contaminated as a result of uranium and thorium processing and disposal activities that took place from the 1940s through the 1960s. The chemical plant area, the focus of this study, contains about 40 buildings and support structures (currently in the process of being dismantled), four raffinate pits, two ponds (Ash Pond and Frog Pond), two former dumps (North Dump and South Dump), and a former coal storage area (Figure 2). A remedial investigation/feasibility study (RI/FS) was prepared to evaluate remedial actions at the chemical plant area. Important compenents of the RI/FS included aquifer characterization and numerical modeling to develop an understanding of the hydrogeological characteristics of a shallow limestone aquifer beneath the site.

This paper describes the hydrogeologic characterization studies that were performed to provide the framework upon which the groundwater flow model was developed, calibrated, and used to support decisions regarding remedial actions at the chemical plant area of the Weldon Spring site.

Fig. 1. Location of the Weldon Spring Site (Source: Ref. 1)

Fig. 2. General Layout of the Chemical Plant Area (Source: Ref. 1)

\section{GEOLOGICAL CHARACTERISTICS}

The Weldon Spring site lies at the southern edge of the Dissected Till Plains, a subdivision of the Central Lowlands Physiographic Province, and is characterized by gently rolling hills in upland areas. The surface drainage divide between the tributaries of the Mississippi River to the north and the Missouri River to the south bisects the site in a northeasterly direction (2). Gently rolling topography characterizes the area 
to the north and west, whereas the terrain to the south and east is heavily wooded, rugged, and ravined (3).

The bedrock stratigraphy in the area of the site is composed of approximately 610 to $915 \mathrm{~m}$ of Paleozoic marine limestone, dolomite, sandstone, and shale. The uppermost units at the site are the Mississippian Burlington and Keokuk limestones overlain by 5 to $18 \mathrm{~m}$ of unconsolidated surficial materials composed of topsoil, loess, glacial drift, and residuum. The bedrock units are lithologically similar and have therefore been grouped together by most investigators into the Burlington-Keokuk Limestone. The thickness of this limestone is estimated to be approximately 12 to $56 \mathrm{~m}$ at the site (4). In general, this formation is composed of fine- to coarse-grained limestone with abundant chert occurring as nodules and beds (2).

Subsurface data collected from 92 vertical and 2 angle collected at the site were used to describe the lithologic characteristics of the Burlington-Keokuk Limestone which is 12 to $56 \mathrm{~m}$ thick in this area (5). On the basis of weathering characteristics, the formation is divided into two lithologic units. The upper zone, which is more weathered than the lower portion of the limestone, is referred to as the "weathered" limestone. The lower zone, which is less weathered, is identified as the "unweathered" limestone. The lithologic contact between these two zones was estimated on the basis of the weathering characteristics from borehole data. The amount of weathering gradually decreases with increasing depth; thus, the lithologic contact between the zones is gradational, and extends up to several meters vertically.

On the basis of the estimated lithologic contact, the weathered limestone at the site ranges in thickness from less than $3 \mathrm{~m}$ to about $15 \mathrm{~m}$. The unit is moderately to highly fractured and slightly to severely weathered. Core sampling from the angled boreholes indicates that fracturing in the unit is predominantly horizontal and irregularly spaced and typically occurs along shaley interbeds, bedding planes, or chert interbeds. Solution features have also been found, but they are either partially or completely filled with clay-sized material. Although some voids occur in the uppermost bedrock, they are generally isolated and display limited vertical or lateral continuity (5). The unweathered portion of the Burlington-Keokuk Limestone is thinly to massively bedded and finely to coarsely crystalline. Both horizontal and vertical fracture densities are significantly lower in the un weathered limestone than in the weathered limestone (6).

The uppermost part of the shallow aquifer also includes unconsolidated residuum overlying the bedrock surface at some locations. This residuum unit is interpreted to be a weathered product of either the Burlington-Keokuk Limestone or the Warsaw Formation, a calcarcous shale and interbedded limestone (7). The residuum consists of clayey gravel to gravelly clay that probably formed prior to the Pleistocene. At the Weldon Spring site, this unit ranges in thickness from 0 to $8 \mathrm{~m}$. The thickness and areal extent of the unit appear to be somewhat affected by bedrock topography. Bedrock lows tend to have a thicker residuum section, whereas bedrock highs have a thinner section (7). Discrete portions of saturated residuum occupy depressions in the bedrock surface.

\section{GROUNDWATER}

The two principal bedrock aquifer systems at the Weldon Spring site include a shallow unconfined aquifer and a deep confined aquifer (Figure 3). These systems are separated by several hundred feet of limestone, dolomite, and shale formations (8). Regionally, the shallow bedrock aquifer system consists primarily of saturated Mississippian and Devonian rocks that range regionally from 76 to $198 \mathrm{~m}$ in thickness, and the deep bedrock aquifer system consists of Ordovician and Upper Cambrian saturated rocks (8). Groundwater that is used to supply drinking water for the area is taken from the deep productive aquifers of the Ordovician/Cambrian bedrock system and from an alluvial aquifer near the Missouri River.

Fig. 3. General Stratigraphy and Hydrostratigraphy of the Woldon Spring Site (Source: Refs. 4, 7, 8) 
The ground water system of interest at the site is the upper unconfined aquifer, which consists of saturated rocks within the Burlington-Keokuk Limestone and discrete occurrences of the overlying saturated residuum. Although relatively unprociuctive, this aquifer is the focus of this study because it has been contaminated as a result of previous site activities and is a likely route for contaminant migration.

A map of the water-table surface constructed from average water levels measured from 1986 through 1992 within the upper aquifer indicates the presence of a groundwater divide that trends northeasterly (Figure 4). Ground water to the north of this divide flows northeast toward a tributary of the Mississippi River, whereas ground water to the south of the divide flows southeast toward the Missouri River (7). Although the water table fluctuates in elevation, it generally remains within the upper bedrock or the highly weathered residuum at the overburden/bedrock interface.

Fig. 4. Map of the Water-Table Surface Constructed from Average Water Levels Measured during 1986 through 1991 (Source: Ref. 9)

\section{AQUIFER CHARACTERIZATION}

Hydraulic conductivities in the bedrock aquifer were estimated from three different hydraulic testing methods: slug tests, pumping tests, and packer tests $(4,10)$. The results of these tests were used in this study to provide a range of hydraulic conductivities for the numerical model and to characterize the aquifer more definitively by estimating hydrostratigraphic relationships within the upper and lower units of the Burlington-Keokuk Limestone.

Slug tests were performed in 39 monitoring wells and 2 piezometers at depths ranging from 0 to $12.2 \mathrm{~m}$ and 2.1 to $32 \mathrm{~m}$ below the top of the Burlington-Keokuk Limestone. Hydraulic conductivity values were also determined from pumping tests conducted at three different areas of the site. The hydraulic conductivities determined from these tests ranged from $1.7 \times 10^{-6}$ to $4.5 \times 10^{-3} \mathrm{~cm} / \mathrm{s}$ with the higher conductivities generally associated with wells completed in the upper zone of the aquifer.

The results of slug and pumping tests, in general, are indicative of the unweathered portion of the Burlington-Keokuk, given that the test intervals for most of the wells are open to both the unweathered and weathered zones of the limestone. In addition, these tests provided information on the horizontal distribution of hydraulic conductivity and the heterogeneous nature of the shallow aquifer beneath the site. For example, the larger hydraulic conductivity values, as determined from slug tests, occurred in areas of saturated residuum and highly fractured and argillaceous weathered bedrock where the limestone. surface is incised by weathering. Ground water flow in these areas is discrete, typical of conduit type flow encountered in solution-modified carbonate terrain.

The hydraulic conductivity values determined from the 46 packer tests in 34 wells ranged from $3.5 \times 10^{7}$ to $6.3 \times 10^{-2} \mathrm{~cm} / \mathrm{s}$. These tests were conducted on discrete intervals throughout the shallow bedrock column during drilling operations. Although the results show considerable variability, the hydraulic conductivity decreases with increasing depth. Specifically, the results of these tests showed that the hydraulic conductivity values, determined from tests conducted in the shallow bedrock, were about $90 \%$ smaller than those values determined from tests performed in the deeper bedrock. The occurrence of larger hydraulic conductivity values in shallow test locations is probably attributable to greater effective porosity as a result of weathering. These observations suggest that the aquifer is vertically heterogeneous with respect to hydraulic conductivity. The vertical variation in hydraulic conductivity, determined from all the packer test data, was useful for estimating hydrostratigraphic relationships withm the Burlingtor Keokuk Limestone.

In summary, groundwater flow through the shallow aquifer system is predominantly controlleci by a zone of fracturing and weathering in the upper portion of the aquifer. Diffuse Darcian groundwater flow is manifested in the shallow bedrock aquifer through predominantly horizontal flow occurring in the uppermost part of the aquifer, which is generally strongly weathered and contains fractures along bedding 
planes, vuggy porosity, and small voids. Assuming an interconnection between these upper highly conductive layers and the fracture zones, the Burlington-Keokuk aquifer at the Weldon Spring site can be conceptually modeled as a two-layer hydrogeological system. The thin upper zone, which is more variable and generally has a higher hydraulic conductivity, is assumed to overlie a relatively thick zone with a much lower hydraulic conductivity (7).

\section{NUMERICAL MODEL}

\section{Development}

A three-dimensional ground water flow model was chosen because of its ability to address sufficiently the vertical variations in hydraulic conductivity present in the bedrock below the site. The numerical code selected to model the site was the Coupled Fluid, Energy, and Solute Transport (CFEST) computer code (11). The finite-element grid was developed for the model on tive basis of site-specific information. The grid was designed to be consistent with the areal extent of the region of interest, the boundary conditions, and other important surface features (e.g., ponds, raffinate pits, and observation wells). The finite-element grid (Figure 5) developed for the site consists of 1,939 surface nodes and 1,863 quadrilateral surface elements encompassing an area of approximately 204 ha. The nodal spacing in the raffinate pit area was about $15.2 \mathrm{~m}$, with each element occupying an area of $232 \mathrm{~m}^{2}(9)$.

Fig. 5. Finite-Element Grid for the Numerical Model (Source: Ref. 9)

The unconfined aquifer, consisting of the Burlington-Keokuk Limestone and residuum, was divided into upper and lower zones on the basis of weathering characteristics and hydraulic properties determined from numerous on-site borings and aquifer characterization tests, as discussed above. In the calibrated model, the combined thickness of the saturated residuum and the weathered limestone ranges from 1 to $4 \mathrm{~m}$ in the modeling area. The lower, more competent unit underlying the weathered limestone is 27.5 to $52 \mathrm{~m}$ thick.

The areal boundary conditions incorporated into the model are shown in Figure 6. A segment of the northwest boundary, which parallels a flow line, was modeled as a no-flow (Neumann) boundary. The other boundaries were assigned a constant-head (Dirichlet) condition on the basis of a map of the watertable surface contoured from average water levels measured over a five-year period (Figure 4).

In cross section, the model was assumed to be bounded on the bottom by the Fern Glen Limestone, a lowpermeability unit. Although some vertical leakage is likely to occur between the lower competent Burlington-Keokuk Limestone and underlying formations, the effect of the leakage is not expected to significantly affect groundwater flow in the unconfined aquifer. The bottom boundary was therefore simulated as a no-flow condition. The top boundary, which corresponds with the water-table elevation, was simulated as a constant-flux boundary to represent recharge from precipitation (9).

Continuous uniform values of hydraulic conductivity were selected for modeling the unweathered zone of the Burlington-Keokuk Limestone. However, heterogeneity for the upper weathered limestone of the Burlington-Keokuk was incorporated in the model by increasing the hydraulic conductivity in the northern area of the site. Packer and slug tests conducted in wells located in the northern half of the site resulted in most of the high hydraulic conductivity values. Field evidence for a high conductivity feature in this area includes the shape of the water-table contours, the configuration of the underlying bedrock topography, and the hydrostratigraphy. As shown in Figure 4, the water-level contours at the northern portion of the site form a clearly discernible trough, which indicates a predominantly northern groundwater flow. The map of the bedrock topography (Figure 6) shows the presence of two paleochannels in the northern section of the chemical plant area. The hydrogeology of these paleochannels is characterized by associated zones of intense weathering that are likely to produce areas of higher conductivity. In addition, water levels measured in several of the monitoring wells in this area occur above the weathered bedrock in the more permeable residuum (Figure 7). 
Fig. 6 Bedrock Topography in the Study Area (Source: Modified from Ref. 7)

Fig. 7 Depth to Groundwater in the Upper 10 Feet of Bedrock (Source: Modified from Ref. 7)

Calibration/Sensitivity Analysis

The groundwater flow model was calibrated in a two-stage process with water-level data collected from 1986 through 1991. The first stage involved comparing contour maps of the model-predicted water-level elevations with a map of the water table contoured from average water levels measured in the field during this five-year period. After the general configurations of the model-predicted and field-measured watertable maps were similar, the second and final stage of the calibration process was implemented. In this stage, the simulation results were compared directly with the water levels measured at 33 monitoring wells. The model was assumed to be calibrated after determining the set of input parameters that produced the smallest sum of squared differences between the model-predicted water-level elevations and those measured in the field. The water-table surface predicted by the calibrated model for the unconfined aquifer is shown in Figure 8.

Fig. 8 Model-Predicted Water-Table Surface (Source: Ref. 9)

The calibration included varying the hydraulic conductivity values for the weathered and unweathered zones of the aquifer within the range of values determined from field investigations. The steady-state calibrated hydraulic conductivities for the lower unweathered zone and upper weathered zone, except for the elements in the northwestern area of the grid, were $4.0 \times 10^{-7}$ and $4.6 \times 10^{-3} \mathrm{~cm} / \mathrm{s}$, respectively. The calibrated hydraulic conductivity value assigned to an array of elements in the north-central area of the chemical plant area was $4.4 \times 10^{-2} \mathrm{~cm} / \mathrm{s}$. To simulate a transitional decrease in hydraulic conductivity from $4.6 \times 10^{-3}$ to $4.4 \times 10^{-2} \mathrm{~cm} / \mathrm{s}$, the elements surrounding this area of high hydraulic conductivity were assigned an intermediate value of $1.8 \times 10^{-2} \mathrm{~cm} / \mathrm{s}$.

The results of the sensitivity analysis showed that the model was most sensitive to changes in hydraulic conductivity. The model was more sensitive to changes in the regional hydraulic conductivity of the weathered unit, whereas changes in hydraulic conductivity of the unweathered zone did not significantly affect the calibration. This sensitivity occurred because the weathered unit has much higher regional hydraulic conductivity (i.e., several orders of magnitude larger) than the unweathered zone and, therefore, dominates the flow-field dynamics.

\section{Model Application}

Alternative remedial actions for the chemical plant area of the Weldon Spring site were developed and evaluated as part of the feasibility study for the Weldon Spring Site Remedial Action Project (1). The feasibility study identified remediation technologies and process options that are potentially applicable to the various contaminated media associated with the site. From evaluation of the final alternatives, DOE identified the preferred alternative for remedial action at the site. Under the preferred alternative, material would be removed from contaninated areas and treated, as appropriate, and all site wastes would be disposed of in an engineered disposal cell constructed on-site (12).

The southern boundary of a conceptual on-site disposal cell coincides with the groundwater divide. Figure 8 illustrates the model-predicted water-table surface at the site, including the location of the proposed disposal cell. The model-predicted ground water flow direction and the relative ground water velocities at the site for the unconfined aquifer are shown in Figure 9 (arrows show flow directions). Evaluation of the steady-state groundwater flow velocity plots indicates that groundwater would flow beneath the disposal cell along natural gradients and would not stagnate beneath the cell. The remediation capability for groundwater contamination would not be significantly impacted by the presence of the disposal cell (9). 
Fig. 9 Groundwater Flow Directions and Relative Velocities at the Site, Including the Location of the Potential On-Site Disposal Cell (Dashed Line) (Source: Ref. 9)

\section{CONCLUSIONS}

Aquifer characterization studies were performed, and a three-dimensional grcund water flow model was developed and calibrated for the Weldon Spring site west of St. Louis, Missouri. Slug and pumping tests provided information on the horizontal distribution of hydraulic conductivity, and packer tests and lithologic information were valuable in defining hydrostratigraphic units and the vertical distribution of hydraulic conductivity. The numerical model validated the conceptual, formulated from field studies, and improved the understanding of the shallow groundwater system. A number of issues were addressed, including preferential flow paths within the shallow groundwater system and possible constraints on future cleanup activities.

This study illustrates the value of combining field investigations with numerical modeling to improve understanding of the groundwater system at a site. It also shows that combining field studies and numerical modeling a useful tool can be developed to support decisions regarding remedial action.

\section{ACKNOWLEDGMENTS}

This work was supported by the U.S. Department of Energy, Assistance Secretary for Environınental Restoration and Waste Management, under contract W-31-109-Eng-38.

\section{REFERENCES}

1. U.S. DEPARTMEN'T of ENERGY, "Feasibility Study for Remedial Action at the Chemical Plant Area of the Weldon Spring Site," DOE/OR/21548-148, Vols. I-II, prepared by Argonne National Laboratory, Environmental Assessment and Information Sciences Division, Argonne, III. (Nov. 1992).

2. MK-FERGUSON COMPANY and JACOBS ENGINEERING GROUP, "Aquifer Characteristics Data Report for the Weldon Spring Site Chemical Plant/Raffinate Pits and Vicinity Properties," DOE/OR/21548-122, Rev. 0, Weldon Spring Remedial Action Project, St. Charles, Mo. (Nov. 199()).

3. J.M. PETERSON et al., "Work Plan for the Remedial Investigation/Feasibility Study-Environmental Impact Statement for the Weldon Spring Site, Weldon Spring, Missouri," DOE/OR/21548-033, prepared by Argonne National Laboratory, Environmental Assessment and Information Sciences Division, Argonne, Ill. (Aug. 1988).

4. J.W. WHITFIELD, K.G. BRILL, and W.J. KRUMMEL, "Geologic Map of the Weldon Spring 7.5 Quadrangle, St. Charles County, Mo.," OFM-89-252-Gl, Missouri Department of Natural Resources, Division of Geology and Land Survey, Rolla, Mo. (1989).

5. J. CARMAN, "Aquifer Characteristics of the Shallow Burlington-Keokuk Limestone at the Weldon Spring Site," pp. 155-201 in Proceedings of the Ceesciences Workshop, DOE/OR/21548-197, published by MK-Ferguson Company and Jacobs Engineering Group, Weldon Spring Remedial Action Project, St. Charles, Mo. (Feb. 1991).

6. MK-FERGUSON COMPANY and JACOBS ENGINEERING GROUP, "WSSRAP Chemical Plant Geotechnical Investigations," DOE/OR/21548-158, Weldon Spring Remedial Action Project, St. Charles, Mo. (Dec. 1990).

7. U.S. DEPARTMENT OF ENERGY, "Remedial Investigation for the Chemical Plant Area of the Weldon Spring Site," DOE/OR/21548-(174, Rev. 0, Vols. I-II, prepared by MK-Ferguson Company and Jacubs Engineering Ciroup, Weldon Spring, Mo. (Nov. 1992). 
8. M.J. KLEESCHULTE and L.F. EMMETT, "Hydrology and Water Quality at the Weldon Spring Radioactive Waste Disposal Sites, St. Charles County, Missouri," U.S. Geological Survey Water Resources Investigation Report 87-4169 (1987).

9. L.A. DURHAM, "Modeling Ground water Flow at the Chemical Plant Area of the Weldon Spring Site", ANL/EAIS/TM-79, Argonne National Laboratory, Argonne, 1ll. (Oct 1992).

10. BECHTEL NATIONAL, INC., "Hydrogeological Characterization Report for the Weldon Spring Chemical Plant," DOE/OR/20722-137, Weldon Spring Remedial Action Project, St. Charles, Mo. (July 1987).

11. S.K. GUPTA et al., "Coupled Fluid, Energy, and Solute Transport (CFEST) Model: Formulation and User's Manual," BMI/ONWI-660, Battelle Memorial Institute, Office of Nuclear Waste Isolation, Columbus, Ohio (Oct. 1987).

12. U.S. DEPARTMENT OF ENERGY, "Proposed Plan for Remedial Action at the Chemical Plant Area of the Weldon Spring Site," DOE/OR/21548-160, prepared by Argonne National Laboratory, Environmental Assessment and Information Sciences Division, Argonne, Ill. (Nov. 1992). 


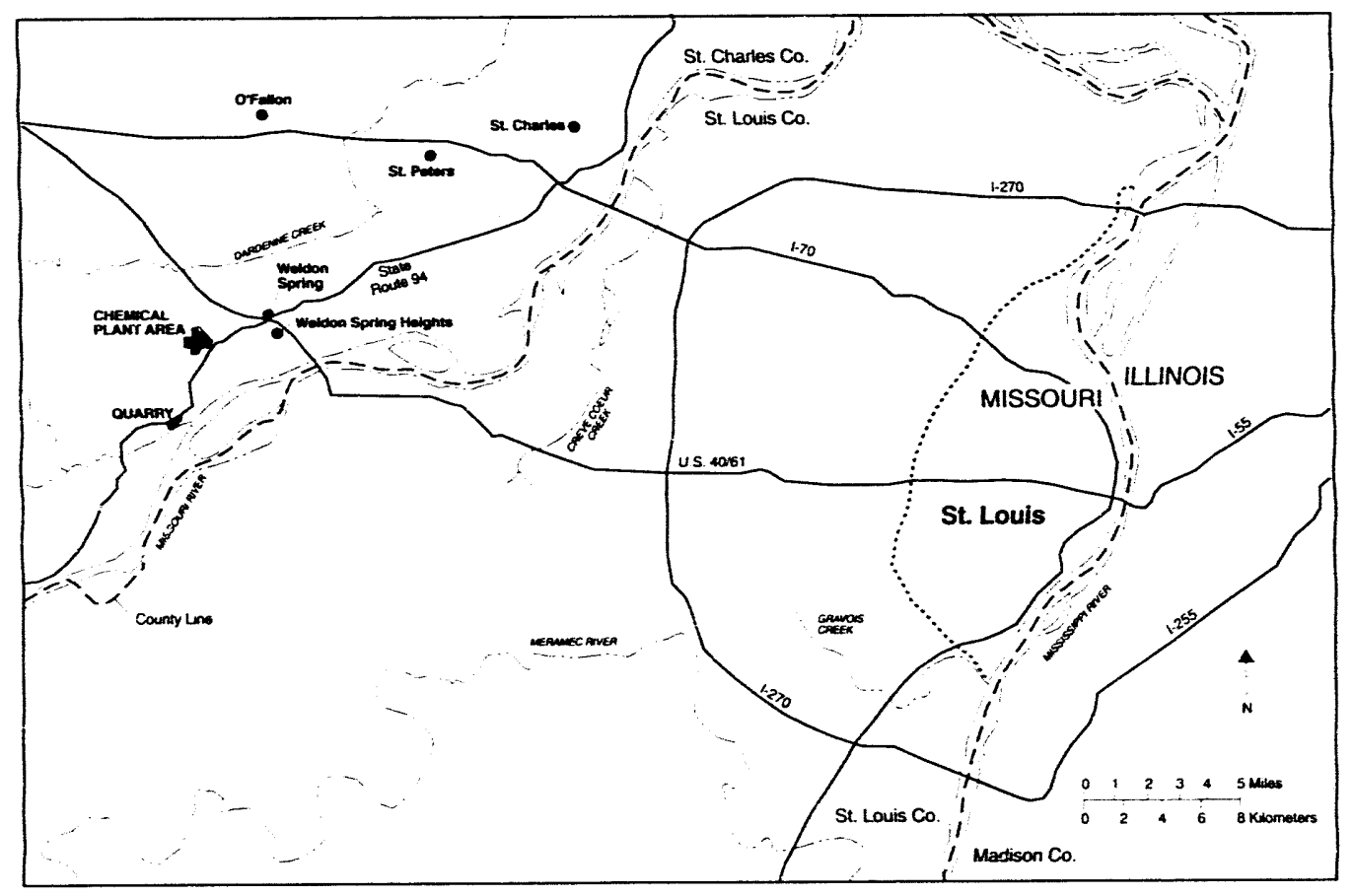




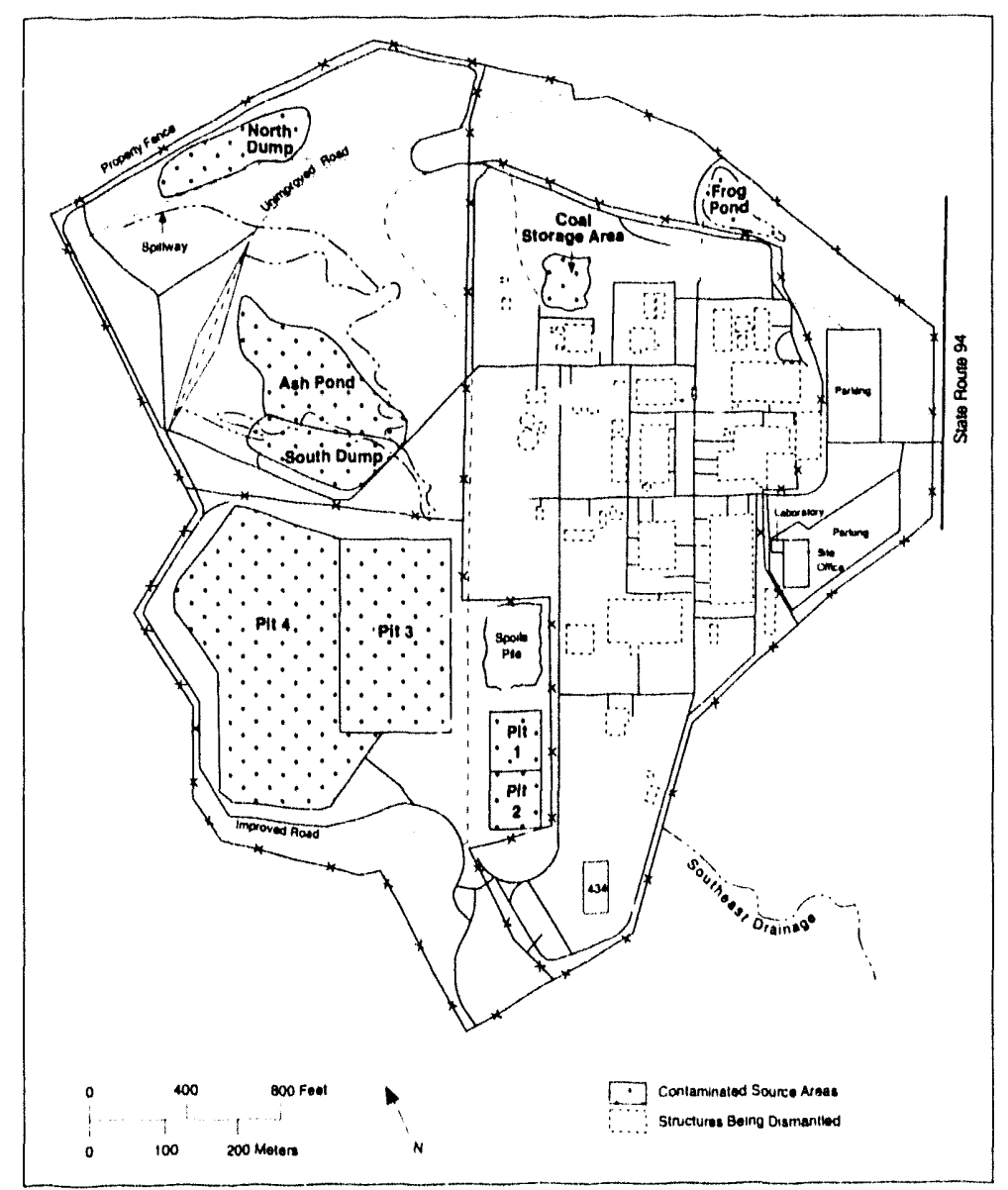




\begin{tabular}{|c|c|c|c|c|c|}
\hline Syatom & sortees & Strestoresphe Unith & Typolces & 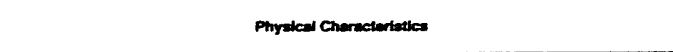 & 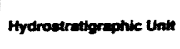 \\
\hline \multirow{2}{*}{ Oueternary } & Hotocenere & Alumum & 02.4 & Gravelly, sily barm & Nhumel Aquiter \\
\hline & Plessoconente & Loess, Giacal Drth & 5.17 & 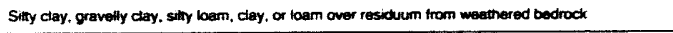 & (Unseturation) \\
\hline \multirow{6}{*}{ Mussisstposan } & \multirow{2}{*}{ Meramecian } & Salem Formaton & 0.5 & 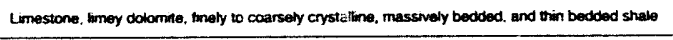 & \multirow{4}{*}{ (Unseaturateo) } \\
\hline & & Warsaw Formation & $18-24$ & 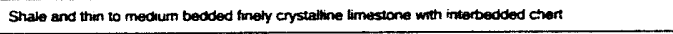 & \\
\hline & \multirow{2}{*}{ Osagoan } & 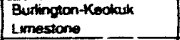 & 30.51 & 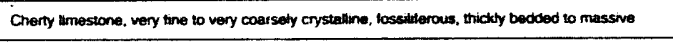 & \\
\hline & & Forn Gian Limestionse & 14.21 & 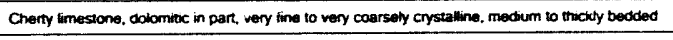 & \\
\hline & \multirow{2}{*}{ Kmoamookian } & Chourasu Group & 6.15 & 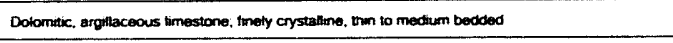 & \multirow{2}{*}{$\begin{array}{l}\text { ussisspplen-Devorien } \\
\text { Aquiter System }\end{array}$} \\
\hline & & Ousthery Sandsione & 2.6 & Ouartz arentite, thre to modum gramed, trable & \\
\hline Devoman & Hoper & 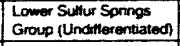 & 0.06 & 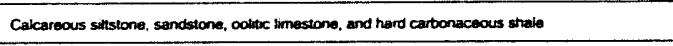 & \multirow{6}{*}{$\begin{array}{l}\text { Ordovican Laaky } \\
\text { Contring Unit }\end{array}$} \\
\hline \multirow{11}{*}{ Orosonctan } & Cancinnaban & Maquokoters Shate & 3.9 & 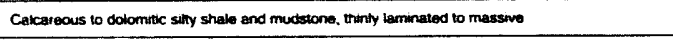 & \\
\hline & \multirow{5}{*}{ Champlanian } & Kemmsinck Limestone & $21 \cdot 30$ & 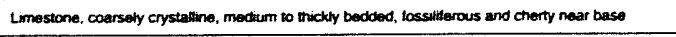 & \\
\hline & & Decorath Group & 9.18 & 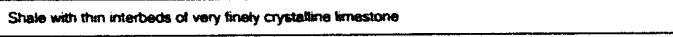 & \\
\hline & & Praten Lmestione & $30-40$ & 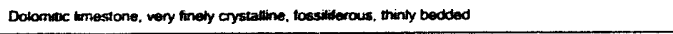 & \\
\hline & & Jaechem Dolorminte & 24.32 & 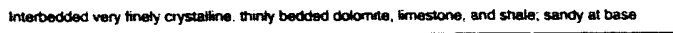 & \\
\hline & & St. Poter Sandstone & 37.48 & Ouartz aremte, fino io medium gramed, massine & \multirow{8}{*}{ 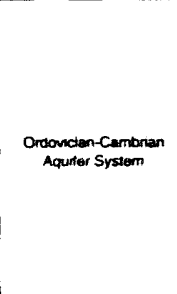 } \\
\hline & \multirow{5}{*}{ Canatian } & Powet Dookmine & $15-18$ & 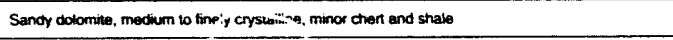 & \\
\hline & & Conter Dolomine & 61.76 & 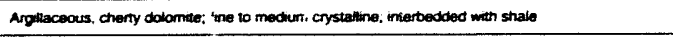 & \\
\hline & & Setherson Ciry Dolomate & $49-55$ & Dobonta, fine to modium crystateino & \\
\hline & & Howbicour Formation & 46-52 & Dalomixic sanctstione & \\
\hline & & Gasconedo Dolomine & 76 & 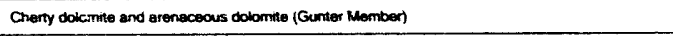 & \\
\hline \multirow{2}{*}{ Cambran } & \multirow{2}{*}{ uppor } & Emmences Dolomita & 61 & 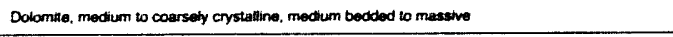 & \\
\hline & & Potos Dolontis & 30 & 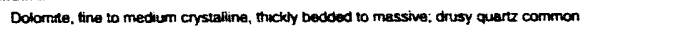 & \\
\hline
\end{tabular}




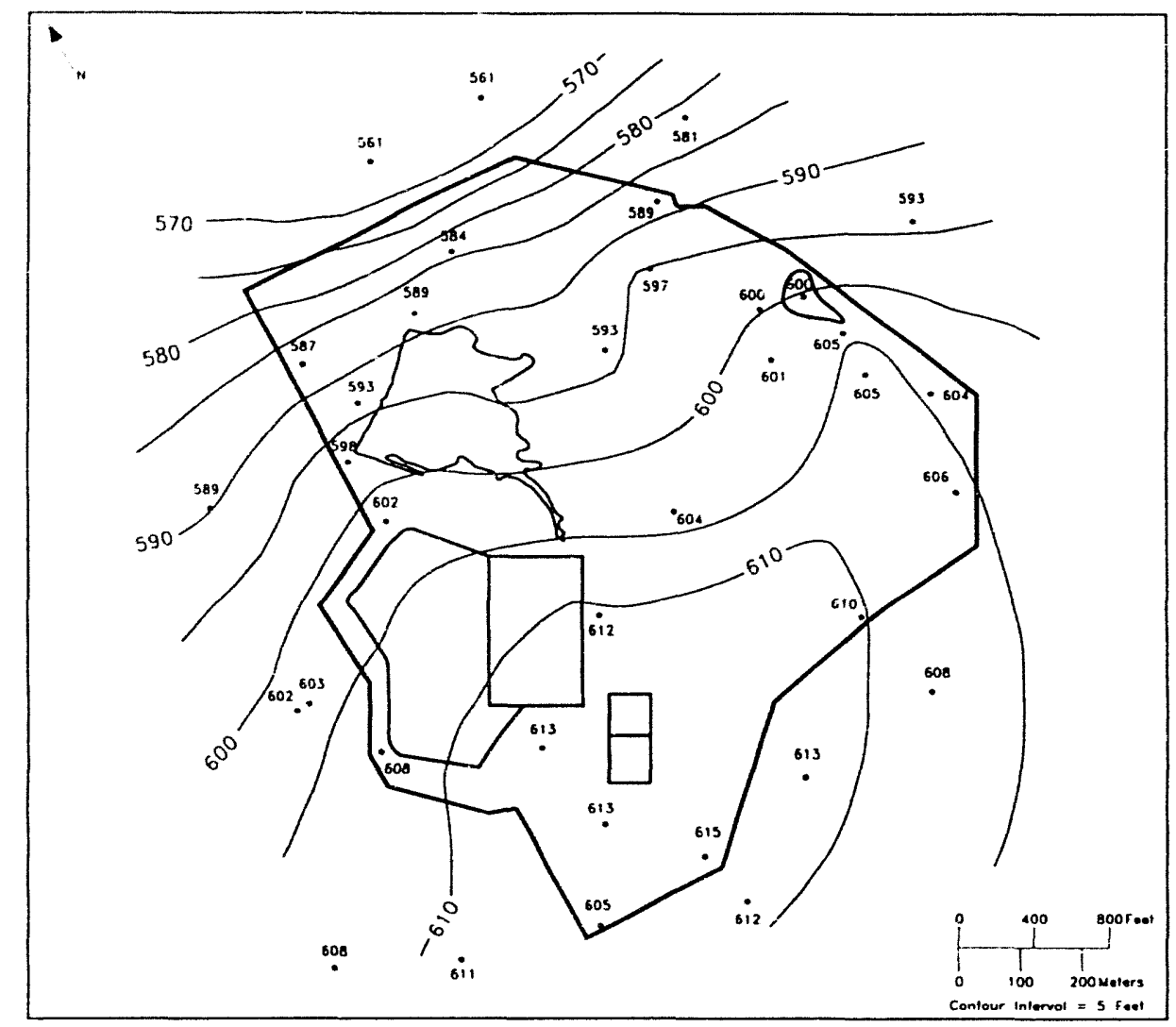




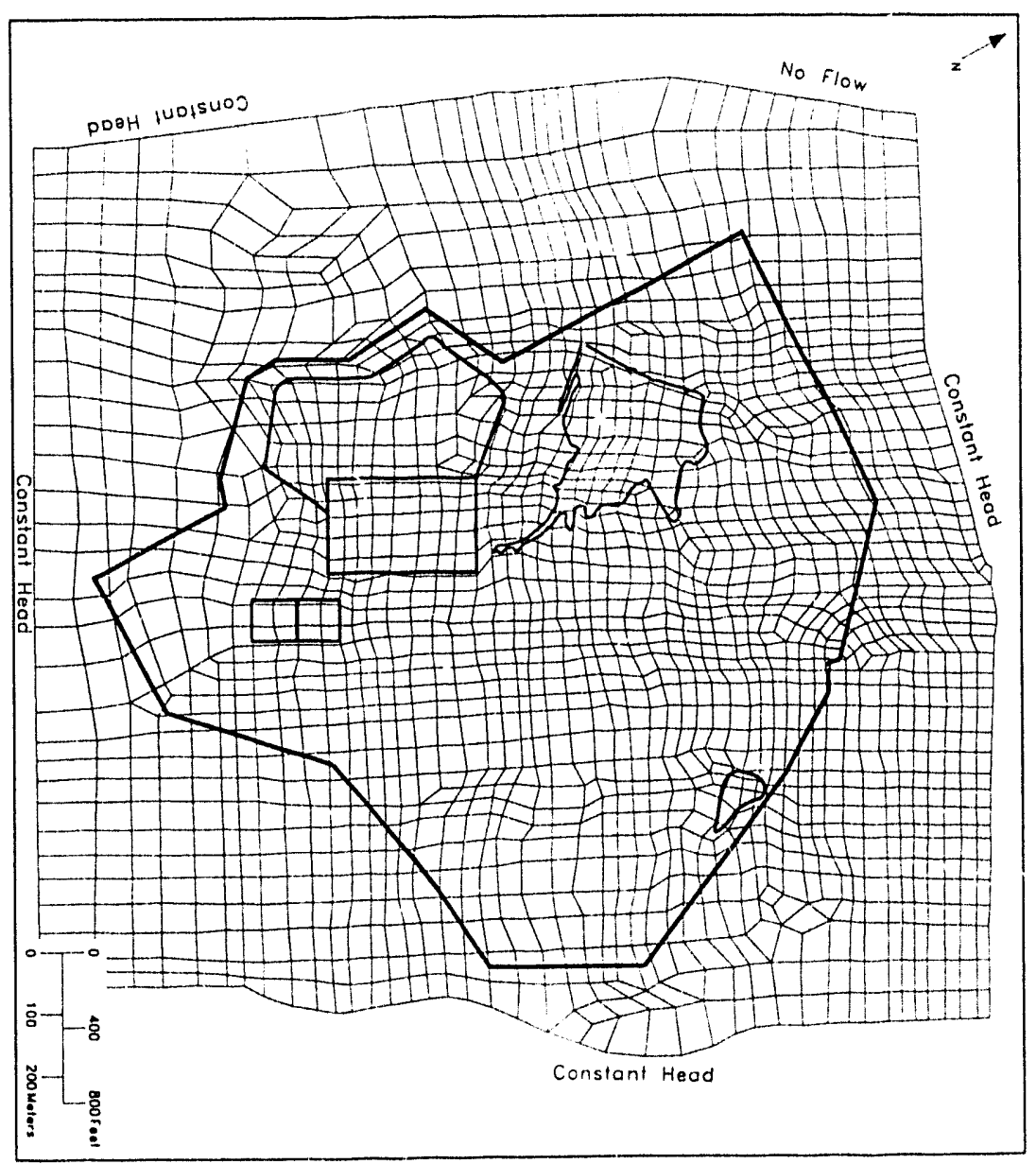




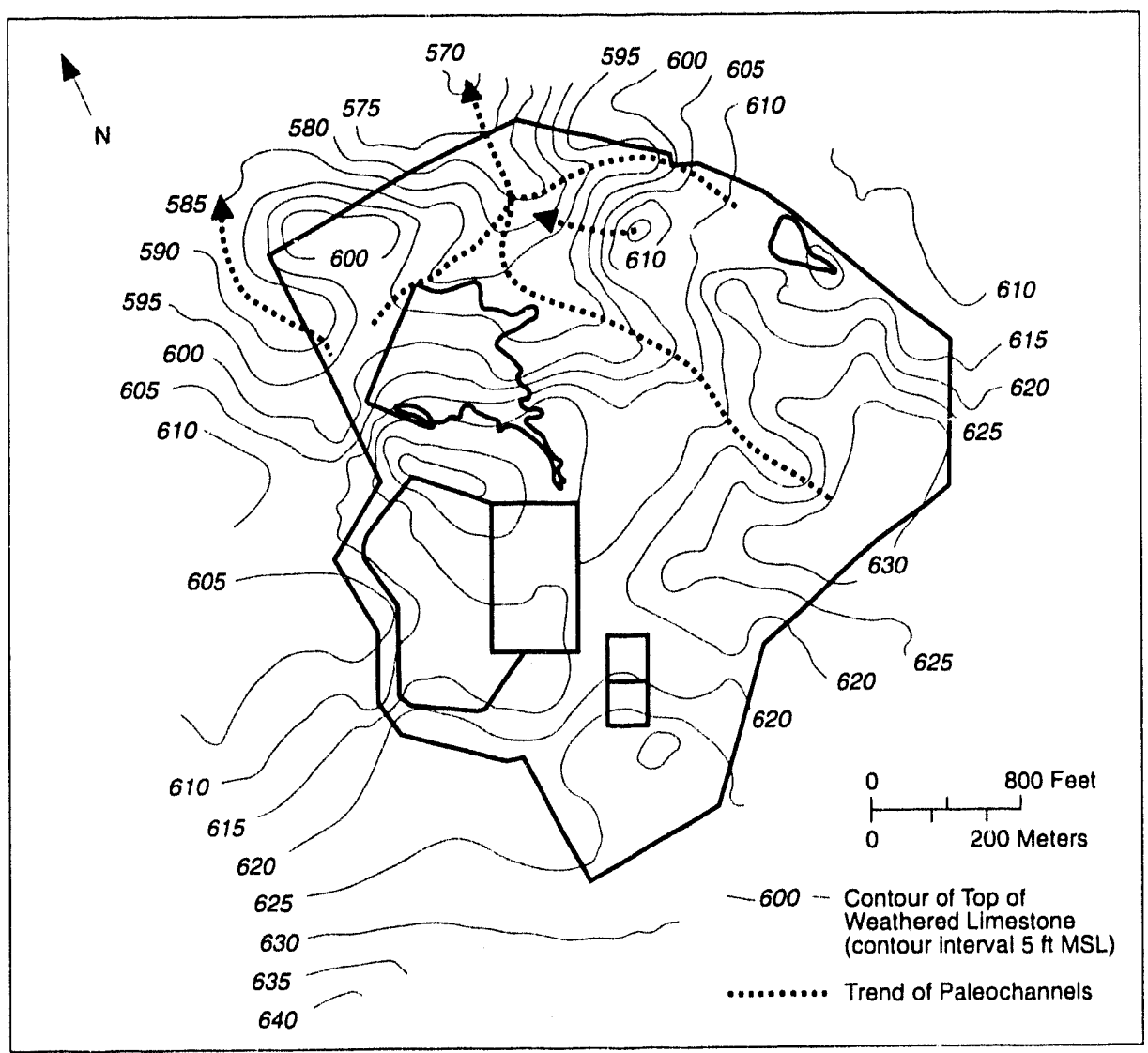




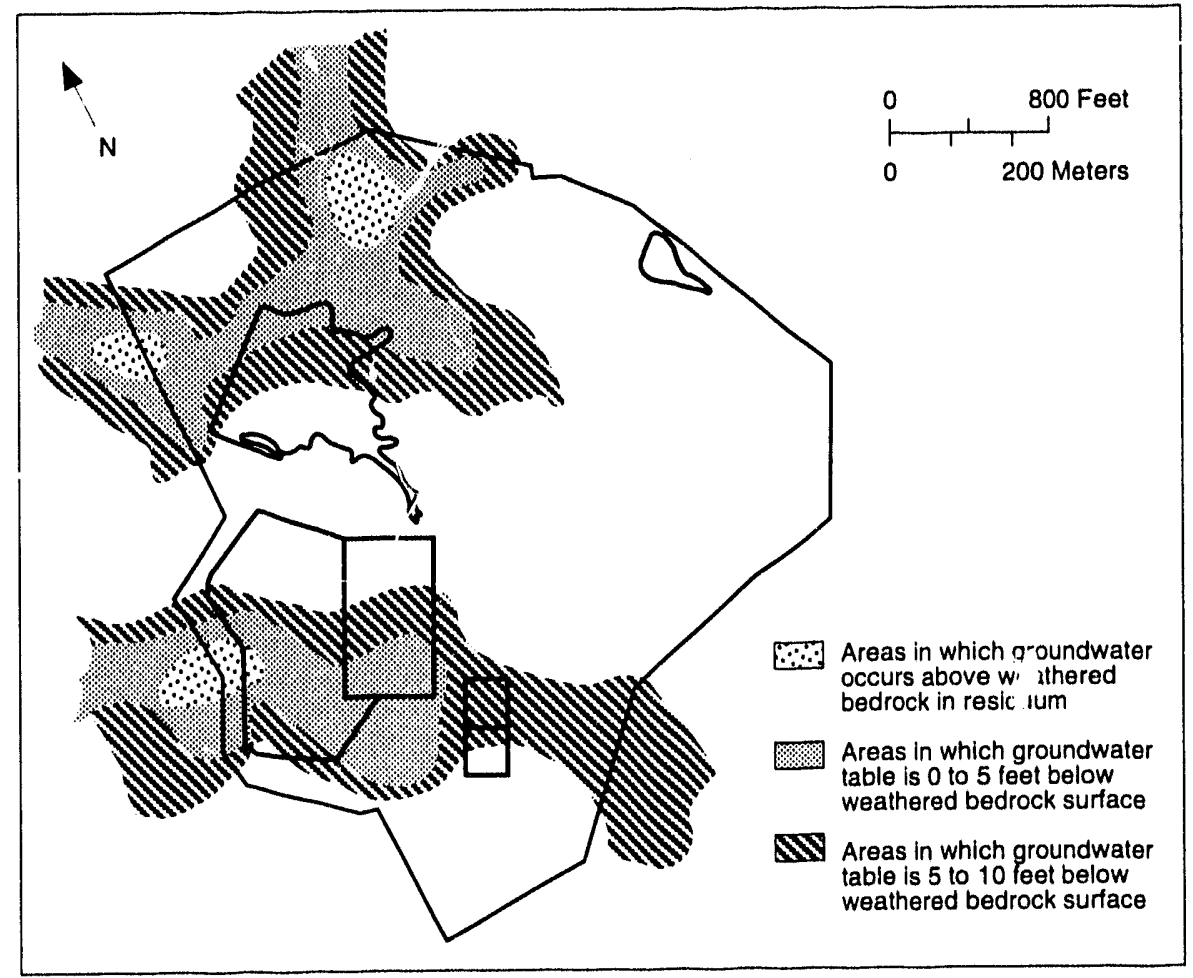




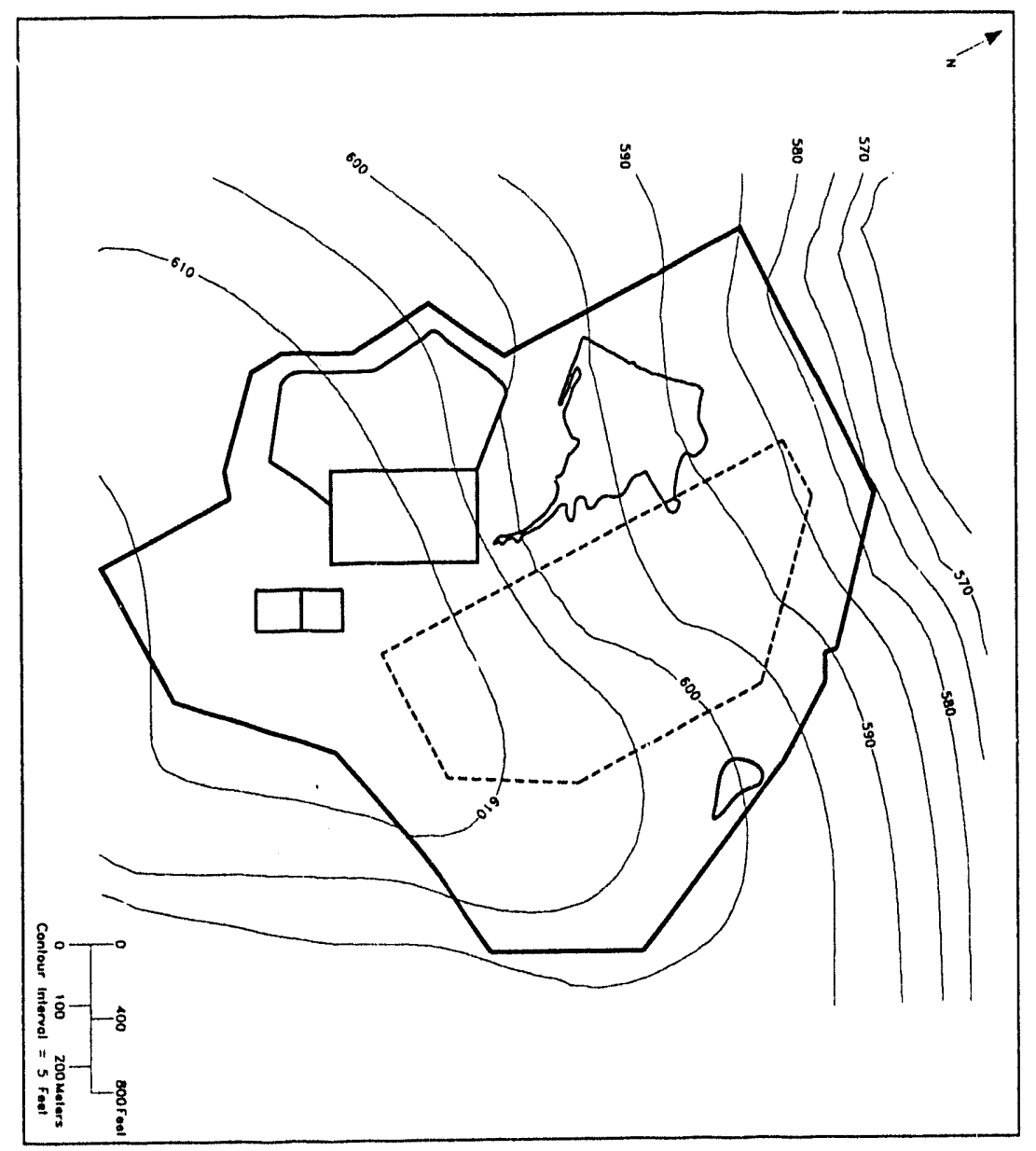

1 

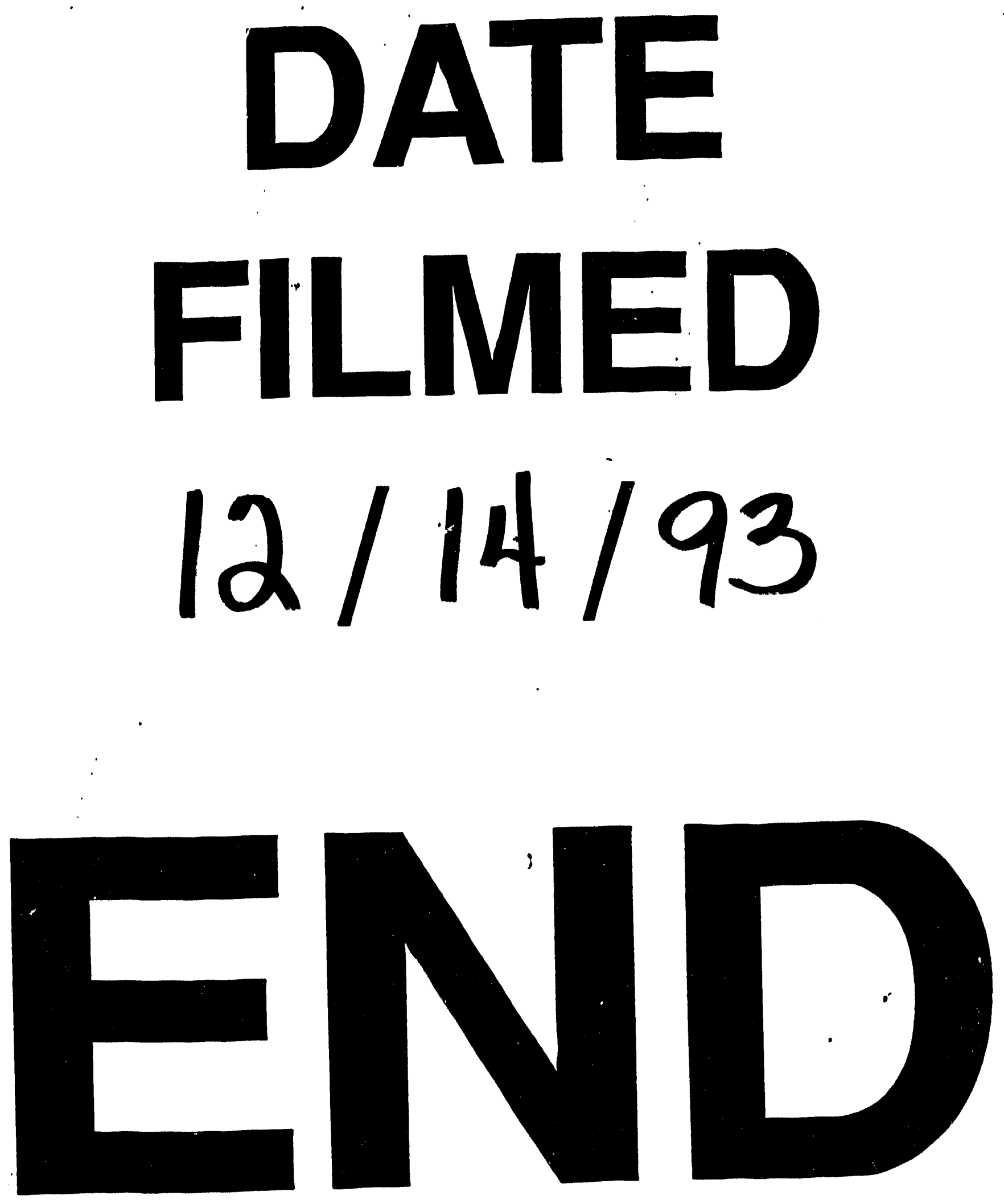
